\title{
PENGARUH MODEL PROBLEM POSING DENGAN MEDIA MAKET TERHADAP PENINGKATAN BERPIKIR KRITIS DAN AKTIVITAS BELAJAR BIOLOGI PESERTA DIDIK KELAS X PADA MATERI KEANEKARAGAMAN HAYATI DI SMA NEGERI 6 BANDAR LAMPUNG
}

\author{
${ }^{1}$ Indarto dan ${ }^{2}$ Iftika Nurfalitasari \\ 1,2,3 Universitas Islam Negeri Raden Intan Lampung. J1. H Endro Suratmin Sukarame- \\ Bandar Lampung (0721)70326): indarto@radenintan.ac.id
}

Diterima : 07 Agustus 2017. Disetujui: 15 Desember 2017. Dipublikasikan: 29 Desember 2017

\begin{abstract}
ABSTRAK
Penelitian ini dilatarbelakangi oleh keterampilan berpikir kritis peserta didik masih rendah. Selama ini guru hanya menggunakan metode pembelajaran ceramah dan diskusi. Proses pembelajaran peserta didikkelas X MIA SMA Negeri 6 Bandar Lampung kurang mampu mengembangkan kemampuan berpikir kritis dan aktivitas belajar, sehingga dibutuhkan inovasi baru dalam pembelajaran biologi untuk mengembangkan kedua kemampuan tersebut. Tujuan penelitian ini adalah (1) mengetahui pengaruh model problem posing dengan media maket terhadap kemampuan berpikir kritis peserta didik kelas X di SMA Negeri 6 Bandar Lampung, dan (2) mengetahui pengaruh model problem posing dengan media maket terhadap aktivitas belajar biologi peserta didik kelas X di SMA Negeri 6 Bandar Lampung.

Metode penelitian yang digunakan adalah Quasi eksperimental design. Populasi penelitian adalah seluruh peserta didik kelas X MIA SMA Negeri 6 Bandar Lampung dan sampel penelitian adalah peserta didik kelas $X$ Mia 2 sebagai peserta didik eksperimen dan kelas X MIA 3 sebagai kelas kontrol yang dipilih secara acak kelas. Teknik pengumpulan data yang digunakan adalah tes kemampuan berpikir kritis dan angket aktivitas belajar siswa. Setelah butir soal tes dan angket telah diproses analisis data diperoleh 8 butir soal tes kemampuan kemampuan berpikir krirtis dan 23 pernyataan angket aktivitas belajar yang dinyatakan layak untuk digunakan dalam penelitian.

Berdasarkan hasil uji normalitas dan uji homogenitas, diperoleh bahwa data hasil tes dari kedua kelompok tersebut normal dan homogen. Selanjutnya uji hipotesis yang telah digunakan uji t diperoleh kesimpulan bahwa (1) terdapat pengaruh yang signifikan pada penggunaan model problem posing dengan media maket terhadap peningkatan berpikir kritis terhadap peserta didik kelas X di SMA Negeri 6 Bandar Lampung,(2) terdapat pengaruh yang signifikan pada penggunaan model problem posing dengan media maket terhdap aktivitas belajar terhadap peserta didik kelas X di SMA Negeri 6 Bandar Lampung. Dengan Peningkatan $\mathrm{N}$-gain Berpikir kritis70\% dan aktivitas belajar $50 \%$.
\end{abstract}

Kata Kunci: Model Problem Posing, Media Maket, Keanekaragaman Hayati, Berpikir Kritis, Aktivitas Belajar. 


\begin{abstract}
This research is motivated by the critical thinking skills of students is still low. During this time the teacher only using methods pembelajan lecture and discussion. The learning process of learners class Mia X SMAN 6 Bandar Lampung less able to develop critical thinking skills and learning activities, and so we need new innovations in teaching biology to develop both these capabilities. The purpose of this study were (1) the effect of the model problem posing with media mockups of the critical thinking skills of students grade X SMAN 6 Bandar Lampung, and (2) the effect of the model problem posing with media mock-up of the activity of studying biology students of class X SMAN 6 Bandar Lampung.

The method used was Quasi-experimental design. The study population was all students of class X Mia SMAN 6 Bandar Lampung and the sample are students of class $X$ Mia 2 as learners experiment and Mia X grade 3 as the control class randomly selected class. Data collection techniques used were test critical thinking skills and inquiry learning activities of students. After the test items and questionnaires have been processed on data analysis 8 test items and the capability to think krirtis 23 statement questionnaire learning activities which are feasible for use in research.

Based on the results of tests of normality and homogeneity tests, found that the test data from the two groups were normal and homogeneous. Further tests of hypotheses that have been used t test was concluded that (1) there is a significant influence on the use of models problem posing with media mockups to increase critical thinking to students grade X SMAN 6 Bandar Lampung, (2) there is a significant influence on the use of a model problem posing with mock media terhdap learning activities to students of class X SMAN 6 Bandar Lampung. With N-gain Improved Thinking kritis $70 \%$ and $50 \%$ of learning activities.
\end{abstract}

Keywords: Model Problem Posing, Media Maket, Biodiversity, Critical Thinking, Learning activities.

\title{
PENDAHULUAN
}

Pendidikan memegang peranan dan faktor yang sangat penting dalam kehidupan manusia karena merupakan salah satu wahana untuk menciptakan sumber daya manusia yang berkualitas.Pentingnya pendidikan untuk manusia tertuang dalam Undang-Undang Nomor 20 Tahun 2003 bahwa pendidikan merupakan usaha sadar dan terencana untuk mewujudkan suasana belajar dan proses pembelajaran agar secara aktif mengembangkan potensi dirinya. Pendidikan akan mengajarkan manusia untuk mengembangkan potensi dirinya sehingga manusia mampu menghadapi tantangan 
perkembangan ilmu pengetahuan dan teknologi serta mampu mengatasi masalah dalam kehidupan sehari-hari.

Nurulwati (2009) mengemukakan maksud dari model pembelajaran yaitu, kerangka konseptual yang melukiskan prosedur yang sistematis dalam mengorganisasikan pengalaman belajar untuk mencapai tujuan belajar tertentu, dan berfungsi sebagai pedoman bagi para perancang pembelajaran dan para pengajar dalam merencanakan aktivitas belajar mengajar.

Ratna Kartika IrawatiSalah satu model pembelajaran yang dapat digunakan dalam proses pembelajaaran sebagai model pemrosesan informasi ialahProblem posing merupakan model pembelajaran yang mengharuskan peserta didik menyusun pertanyaan sendiri atau memecah suatu soal menjadi pertanyaan-pertanyaan yang lebih sederhana yang mengacu pada penyelesaian soal tersebut.

Ely mengatakan bahwa media dipahami secara garis besar adalah manusia, materi, atau kejadian yang membangun kondisi yang membuat peserta didik mampu memperoleh pengetahuan, keterampilan, atau sikap. Dalam pengertian ini, guru, buku teks, dan lingkungan sekolah merupakan media. Secara lebih khusus, pengertian media dalam proses belajar mengajar cenderung diartikan sebagai alat-alat grafis, photografis, atau elektronis untuk menangkap, memproses, dan menyusun kembali informasi visual atau verbal.Sementara itu Heinich dkk mengemukakan istilah medium sebagai perantara yang mengantar informasi antara sumber dan penerima. Jadi, televisi, film, foto, radio, rekaman audio, gambar yang diproyeksikan, bahan-bahan cetakan, dan sejenisnya adalah media komunikasi.

Menurut Sadiman maket sebuah bangunan adalah model dari bangunan yang sebenarnya tetapi bukan simulasi karena tidak untuk menggambarkan proses.Media tiga 
dimensi memang memiliki kelemahan-kelemahannya, diantaranya yaitu: tidak bisa menjangkau sasaran dalam jumlah yang besar, penyimpanannya memerlukan ruang yang besar dan perawatannya rumit. Namun hal ini dapat ditutupi dengan kelebihan yang dimilikinya yaitu sebagai berikut: Bentuknya yang dibuat dalam tiga dimensi seperti aslinya(dalam bentuk miniatur), ditambah dengan pemberian warna secara realistik dan pemberian bayangan yang digunakan untuk mengarahkan perhatian dan membedakan komponen-komponen dapat memberikan kesan yang menarik bagi siapa saja yang memandang.

Seperti yang diungkapkan oleh Moedjiono, media tiga dimensi memiliki kelebihan-kelebihan: memberikan pengalaman secara langsung, penyajian secara kongkrit dan menghindari verbalisme, dapat menunjukkan obyek secara utuh baik konstruksi maupun cara kerjanya, dapat memperlihatkan struktur organisasi secara jelas, dapat menunjukkan alur suatu proses secara jelas, maka dengan itu diharapkan dapat meningkatkan daya ingat peserta didik terhadap informasi pembelajaran yang terkandung dalam media tersebut.

Suryanti dkk yaitu: berpikir kritis merupakan proses yang bertujuan untuk membuat keputusan yang masuk akal mengenai apa yang kita percayai dan apa yang kita kerjakan. Berpikir kritis merupakan salah satu tahapan berpikir tingkat tinggi. Sugiarto mengkategorikan proses berpikir kompleks atau berpikir tingkat tinggi ke dalam empat kelompok yang meliputi pemecahan masalah (problem solving), pengambilan keputusan (decision making), berpikir kritis (critical thinking), dan berpikir kreatif (creative thingking).

Glaser mendefinisikan berfikir sebagai berikut: (1) suatu sikap mau berpikir secara mendalam tentang masalah-masalah dan hal-hal yang berada dalam jangkauan 
pengalaman seseorang; (2) pengetahuan tentang metode-metode pemeriksaan dan penalaran yang logis; dan (3) semacam suatu keterampilan untuk menerapkan metodemetode tersebut. Sedangkan menurut Robert Ennis berfikir kritis adalah pemikiran yang masuk akal dan reflektif yang berfokus untuk memutuskan apa yang mesti dipercaya atau dilakukan.Amri dan Ahmadi dalam berpikir kritis siswa dituntut menggunakan strategi kognitif tertentu yang tepat untuk menguji keandalan gagasan, pemecahan masalah, dan mengatasi masalah serta kekurangannya. Hal ini sejalan dengan pendapat Sugiarto, bahwa berpikir kritis merupakan berpikir disiplin yang dikendalikan oleh kesadaran.

Menurut kimble, belajar adalah perubahan yang relative permanen didalam behavioral potentionality (potensi behavioral) sebagai akibat dari reinforced practice (praktik yang diperkuat). Senada dengan hal tersebut, Mayer menyebutkan bahwa belajar adalah menyangkut adanya perubahan perilaku yang relative permanen pada pengetahuan atau perilaku seseorang karena pengalaman. Menurut Bell-Grendler belajar adalah proses yang dilakukan oleh manusia untuk mendapatkan aneka ragamkemampuan, (competencies), keterampilan (skill), dan sikap (attitude) yang diperoleh secara bertahap dan berkelanjutan.

Menurut Agus Suprijono, pembelajaran aktif adalah pembelajaran yang harus menumbuhkan suasana sedemikian rupa sehingga peserta didik aktif bertanya, mempertanyakan, dan mengemukakan gagasan. Belajar memang merupakan proses aktif dari si pembelajaran dalam membangun pengetahuannya, bukan proses pasif yang hanya menerima kucuran ceramah guru tentang pengetahuan. Pembelajaran aktif adalah proses belajar yang menumbuhkan dinamika belajar bagi peserta didik. Dinamika untuk 
mengartikulasikan dunia idenya dalam mengkonfrontif ide itu dengan dunia ralitas yang dihadapinya.

Menurut Nasution, aktivitas belajar adalah aktivitas yang bersifat jasmani ataupun rohani. Dalam proses pembelajaran, kedua aktivitas tersebut harus selalu terkait. Seorang peserta didik akan berpikir selama ia berbuat, tanpa perbuatan maka peserta didik tidak berpikir. Oleh karena itu agar peserta didik aktif berpikir maka peserta didik harus diberi kesempatan untuk berbuat atau beraktivitas.

Tujuan dari penelitian yaitu Mengetahui Pengaruh Model Problem Posing Dengan Media Maket Terhadap Peningkatan Kemampuan Berpikir Kritis Peserta Didik Kelas X di SMA Negeri 6 Bandar Lampung dan Mengetahui Pengaruh Model Problem Posing Dengan Media Maket Terhadap PeningkatanAktivitas Belajar Biologi Peserta Didik Kelas X di SMA Negeri 6 Bandar Lampung. Adapun manfaat yang diperoleh diharapkan dapat bermanfaat bagi peserta didik, guru, sekolah dan peneliti serta dapat memberikan suatu alternatif model pembelajaran yang dapat diterapkan bagi perorangan maupun institusi.

\section{METODE PENELITIAN}

Penelitian dilaksanakan di SMA Negeri 6 Bandar Lampung pada semester genap tahun pelajaran 2015/2016. Jenis penelitian yang dilakukan dalam penelitian ini adalah penelitian kuantitatif dan metode yang digunakan adalah Quasy Eksperimental dengan desain penelitian Pretest-Posttest Control Group Desain. Populasi dalam penelitian ini adalah peserta didik kelas X SMA Negeri 6 Bandar Lampung, Tahun Pelajaran 2016/2017 sebanyak kelas yang terdiri dari X MIA 1, X MIA 2, X MIA 3, dan X MIA 4. Masing-masing kelas terdapat peserta didik sebanyak 35 orang. Teknik pengambilan sampel pada penelitian ini dilakukan dengan cara acak kelas yaitu membuat suatu 
undian dari 4 kelas tersebut dilakukan pengundian dengan melakukan tiga kali pengambilan.Berdasarkan teknik pengambilan sampel di atas diperoleh sampel sebanyak 2 kelas yaitu kelas X MIA 2 sebagai kelas eksperimen dan X MIA 3 sebagai kelas kontrol. Teknik pengumpulan data pada penelitian ini yang digunakan adalah observasi, wawancara, tes, angket dan dokumentasi.

\section{HASIL PENELITIAN DAN PEMBAHASAN}

Berdasarkan hasil penelitian yang telah dilakukan pada semester genap tahun pelajaran 2015/2016 mengenai pengaruh model problem posing dengan media maket terhadap peningkatan berpikir kritis dan aktivitas belajar biologi peserta didik di SMA Negeri 6 Bandar lampung menghasilkan data sebagai berikut:

\section{Analisis Data Uji Coba Instrumen}

\section{a. Tes Kemampuan Berpikir Kritis}

1) Validitas Tes Kemampuan Berpikir Kritis

Setelah validasi kepada 3 validator tersebut, dilanjutkan dengan uji validitas menggunakan rumus korelasi Product Moment. Harga $a_{i e l}$ diperoleh dengan terlebih dahulu menetapkan derajat kebebasannya menggunakan rumus $=n-2$ pada taraf signifikansi 0,05 atau 5\%. Pada penelitian ini jumlah responden pada saat uji coba tes berjumlah 30, sehingga diperoleh derajat kebebasannya $=30-2=28$ dan tabel Product Moment dengan $=28 \quad$ dan $\alpha=0,05$ diperoleh $\mathrm{e}_{\mathrm{l}}=0,374 \quad$. Apabila $>r_{\text {tabel }}$ maka butir soal tersebut dikatakan valid. Hasil analisis validitas butir tes kemampuan berpikir kritis dapat dilihat pada tabel dibawah ini: 


\section{Tabel 1}

Validitas Soal Tes Kemampuan Berpikir Kritis

\begin{tabular}{cccc}
\hline No. & $\mathbf{r}_{\mathrm{xy}}$ & $\mathbf{r}_{\text {tabel }}$ & Keterangan \\
\hline 1 & 0,348 & 0,374 & Tidak Valid \\
2 & 0,8397 & 0,374 & Valid \\
3 & 0,792 & 0,374 & Valid \\
4 & 0,603 & 0,374 & Valid \\
5 & 0,846 & 0,374 & Valid \\
6 & 0,815 & 0,374 & Valid \\
7 & 0,53 & 0,374 & Valid \\
8 & 0,434 & 0,374 & Valid \\
9 & 0,2059 & 0,374 & Tidak Valid \\
10 & 0,765 & 0,374 & Valid \\
\hline
\end{tabular}

Sumber: Pengelola data Lampiran D.1

Hasil perhitungan validitas butir tes kemampuan berpikir kritis terhadap 10 soal yang diujicobakan menunjukkan terdapat 2 butir soal yaitu butir soal nomor 1 dan nomor 9 yang tergolong tidak valid $\left(\mathrm{r}_{\mathrm{xy}}<0,374\right)$ maka butir soal dengan nomor tersebut tidak diujikan kepada sampel peneliti karena tidak dapat dipakai.

2) Uji Tingkat Kesukaran

Tabel 2

Tingkat Kesukaran Soal Tes Kemampuan Berpikir Kritis

\begin{tabular}{rcc}
\hline \multicolumn{1}{c}{ No. } & $\begin{array}{c}\text { Tingkat } \\
\text { Kesukaran (TK) }\end{array}$ & Keterangan \\
\hline 1 & 0,678 & Sedang \\
2 & 0,278 & Sukar \\
3 & 0,256 & Sukar \\
4 & 0,744 & Mudah \\
5 & 0,290 & Sukar \\
6 & 0,289 & Sukar \\
7 & 0,644 & Sedang \\
8 & 0,789 & Mudah \\
9 & 0,622 & Sedang \\
10 & 0,222 & Sukar \\
\hline
\end{tabular}

Sumber: Pengelola data Lampiran D.2 
Berdasarkan hasil analisis tingkat kesukaran uji coba instrumen tes kemampuan berpikir kritis pada tabel 2, dengan derajat kesukaran sedang, mudah dan sukar sesuai dengan tabel 5 interpretasi tingkat kesukaran butir tes. Dan diperoleh 5 butir soal dengan derajat kesukaran lebih kecil dari 0,30 $(\mathrm{P}<0,30)$ dikategorikan sukar yaitu butir soal nomor 2, 3, 5, 6, dan 10. Butir soal nomor 1, 7, dan 9 dikategorikan sedang karena memiliki derajat kesukaran antara 0,30 dan $0,70(0,30 \leq \mathrm{P} \leq 0,70)$. Sedangkan butir soal nomor 4 dan 8 memiliki derajat kesukaran antara $\mathrm{P}>0,70$ dikaregorikan mudah.

3) Uji Daya Pembeda

Tabel 3

Daya Pembeda Item Soal Tes

\begin{tabular}{ccc}
\hline No. & $\begin{array}{c}\text { DayaPembeda } \\
(\text { DP) }\end{array}$ & Keterangan \\
\hline 1 & 0,6 & Baik \\
2 & 0,9 & BaikSekali \\
3 & 0,9 & Baik Sekali \\
4 & 0,7 & BaikSekali \\
5 & 1,0 & Baik Sekali \\
6 & 1,0 & Baik Sekali \\
7 & 0,9 & Baik Sekali \\
8 & 0,3 & Cukup \\
9 & 0,6 & Baik \\
10 & 0,8 & Baik Sekali \\
\hline
\end{tabular}

Sumber: Pengelola data Lampiran D.4

Pada tabel 3 terlihat bahwa daya pembeda pada butir soal dikategorikan baik, baik sekali dan cukup sesuai dengan tabel 6 klasifikasi daya pembeda. Dan butir soal 1 dan 9 dikategorikan baik dengan daya pembeda berkisar $0,40<\mathrm{D} \leq 0,70$. Dan butir soal nomor 2,3,4,5,6,7 dan 10 dikategorikan baik sekali karena daya pembeda berkisar 0,70 $<\mathrm{D} \leq 1,00$. Dan butir soal nomor 8 dikategorikan cukup karena daya pembeda berkisar $0,20<\mathrm{D} \leq 0,40$.

4) Uji Reliabilitas 
Pada Bab III dijelaskan bahwa suatu tes dikatakan reliabeljika $\mathrm{r}_{\text {hitung }} \geq 0,70$. Berdasarkan hasil perhitungan uji reliabilitas instrumen tes kemampuan berpikir kritis pada Lampiran D.5 diperoleh koefisien reliabilitasnya atau $r_{11}>r$ tabel yaitu $0,705>0,70$, sehingga hasil uji coba tes kemampuan berpikir kritis dinyatakan reliabel dan layak digunakan sebagai instrumen penelitian.

5) Kesimpulan Hasil Uji Coba Tes Kemampuan Berpikir Kritis

Tabel 4

Rekapitulasi Hasil Analisis Butir Soal

\begin{tabular}{ccccc}
\hline $\begin{array}{c}\text { Jomor } \\
\text { Soal }\end{array}$ & Validitas & $\begin{array}{c}\text { Tingkat } \\
\text { Kesukaran }\end{array}$ & $\begin{array}{c}\text { Daya } \\
\text { Pembeda }\end{array}$ & Reliabilitas \\
\hline 1 & Tidak Valid & Sedang & Baik & Reliabel \\
2 & Valid & Sukar & $\begin{array}{c}\text { BaikSekali } \\
\text { Baik }\end{array}$ & Reliabel \\
3 & Veliabel \\
4 & Valid & Sukar & Sekali & \\
5 & Valid & Mudah & BaikSekali & Reliabel \\
& & Sukar & Baik & Reliabel \\
6 & Valid & Sukar & Baik & Reliabel \\
& & & Sekali & \\
7 & Valid & Sedang & Baik & Reliabel \\
8 & Valid & Mudah & Cukup & Reliabel \\
9 & Tidak Valid & Sedang & Baik & Reliabel \\
10 & Valid & Sukar & Baik & Reliabel \\
\end{tabular}

Sumber: Pengelola data Lampiran D.1, D.3, D.4, dan D.5)

\section{b. Angket Aktivitas Belajar}

1) Validitas Angket Aktivitas Belajar

Data uji coba angket aktivitas belajar dianalisis kevalidannya dengan rumus korelasi Product Moment. Harga $\mathrm{r}_{\text {table }}$ diperoleh dengan terlebih dahulu menetapkan derajat kebebasannya menggunakan rumus $=n-2$ pada taraf signifikansi 0,05 atau $5 \%$. Pada penelitian ini jumlah responden pada saat uji coba tes berjumlah 30 , sehingga 
diperoleh derajat kebebasannya $=30-2=28$ dan tabel Product Moment dengan $=28$ dan $\alpha=0,05$ diperoleh ${ }_{\text {tal }}=0,374$. Apabila $>r_{\text {tabel }}$ maka butir soal tersebut dikatakan valid. Hasil analisis validitas butir tes kemampuan berpikir kritis dapat dilihat pada tabel dibawah ini:

Tabel 5

\section{Validitas Butir Angket}

\begin{tabular}{|c|c|c|c|c|c|c|c|}
\hline & $\mathbf{r}_{\mathrm{xy}}$ & $\mathbf{r}_{\text {tabel }}$ & Keterangan & No. & $\mathbf{r}_{\mathrm{xy}}$ & $\mathbf{r}_{\text {tabel }}$ & Keterangan \\
\hline 1 & 0,028 & 0,374 & Tidak Valid & 20 & 0,590 & 0,374 & Valid \\
\hline 2 & 0,791 & 0,374 & Valid & 21 & 0,579 & 0,374 & Valid \\
\hline 3 & 0,698 & 0,374 & Valid & 22 & 0,428 & 0,374 & Valid \\
\hline 4 & $-0,14$ & 0,374 & Tidak Valid & 23 & 0,441 & 0,374 & Valid \\
\hline 5 & 0,795 & 0,374 & Valid & 24 & 0,455 & 0,374 & Valid \\
\hline 6 & 0,584 & 0,374 & Valid & 25 & 0,233 & 0,374 & Tidak Valid \\
\hline 7 & 0,437 & 0,374 & Valid & 26 & 0,217 & 0,374 & Tidak Valid \\
\hline 8 & 0,369 & 0,374 & Tidak Valid & 27 & 0,477 & 0,374 & Valid \\
\hline 9 & 0,398 & 0,374 & Valid & 28 & 0,121 & 0,374 & Tidak Valid \\
\hline 10 & 0,038 & 0,374 & Tidak Valid & 29 & 0,425 & 0,374 & Valid \\
\hline 11 & 0,584 & 0,374 & Valid & 30 & $-0,023$ & 0,374 & Tidak Valid \\
\hline 12 & 0,436 & 0,374 & Valid & 31 & 0,063 & 0,374 & Tidak Valid \\
\hline 13 & 0,354 & 0,374 & Tidak Valid & 32 & 0,267 & 0,374 & Tidak Valid \\
\hline 14 & 0,443 & 0,374 & Valid & 33 & 0,085 & 0,374 & Tidak Valid \\
\hline 15 & 0,390 & 0,374 & Valid & 34 & 0,190 & 0,374 & Tidak Valid \\
\hline 16 & 0,431 & 0,374 & Valid & 35 & 0,500 & 0,374 & Valid \\
\hline 17 & 0,093 & 0,374 & Tidak Valid & 36 & 0,645 & 0,374 & Valid \\
\hline 18 & 0,373 & 0,374 & Valid & 37 & 0,258 & 0,374 & Tidak Valid \\
\hline 19 & 0,672 & 0,374 & Valid & 38 & 0,390 & 0,374 & Valid \\
\hline
\end{tabular}


Berdasarkan interpretasi yang digunakan penulis, perhitungan validitas butir pernyataan angket dinyatakan valid jika $>r_{\text {tabel }} \quad$, maka didapat 17 butir angket yang valid yaitu butir pernyataan angket nomor $2,3,5,6,7,9,11,12,14,15,16,18,19,20$, $21,22,23,24,27,29,35,36$, dan 38.Dua puluh satu butir pernyataan angket yang tidak valid atau $r_{x y}<_{\text {el }} \quad$ yaitu butir angket nomor 1, 4, 8, 10, 13, 17, 25, 26, 28, 30, 31, 32, 33, 34, dan 37.

2) Uji Reliabilitas

Hasil perhitungan uji relibilitas pernyataan angket aktivitas belajar dengan menggunakan rumus Alpha Cronbach pada Lampiran D.6 diperoleh sebesar 0,791. Menurut Anas Sudijono apabila reliabilitasnya lebih besar dari atau sama dengan 0,70, maka angket tersebut dinyatakan reliabel dan memenuhi kriteria layak digunakan sebagai instrumen penelitian.

3) Kesimpulan Hasil Uji Coba Angket Aktivitas Belajar

Tabel 6

Kesimpulan Hasil Uji Coba Angket Aktivitas Belajar

\begin{tabular}{cccccc}
\hline $\begin{array}{c}\text { Nomor } \\
\text { Butir } \\
\text { Angket }\end{array}$ & Validitas & Reliabilitas & $\begin{array}{c}\text { Nomor } \\
\text { Butir } \\
\text { Angket }\end{array}$ & Validitas & Reliabilitas \\
\hline 1 & Tidak Valid & Reliabel & 20 & Valid & Reliabel \\
2 & Valid & Reliabel & 21 & Valid & Reliabel \\
3 & Valid & Reliabel & 22 & Valid & Reliabel \\
4 & Tidak Valid & Reliabel & 23 & Valid & Reliabel \\
5 & Valid & Reliabel & 24 & Valid & Reliabel \\
6 & Valid & Reliabel & 25 & Tidak Valid & Reliabel \\
7 & Valid & Reliabel & 26 & Tidak Valid & Reliabel \\
8 & Tidak Valid & Reliabel & 27 & Valid & Reliabel \\
9 & Valid & Reliabel & 28 & TidakValid & Reliabel \\
10 & Tidak Valid & Reliabel & 29 & Valid & Reliabel \\
11 & Valid & Reliabel & 30 & Tidak Valid & Reliabel \\
12 & Valid & Reliabel & 31 & Tidak Valid & Reliabel \\
13 & Tidak Valid & Reliabel & 32 & Tidak Valid & Reliabel \\
14 & Valid & Reliabel & 33 & Tidak Valid & Reliabel \\
15 & Valid & Reliabel & 34 & Tidak Valid & Reliabel \\
\hline
\end{tabular}




\begin{tabular}{lcllcl}
\hline 16 & Valid & Reliabel & 35 & Valid & Reliabel \\
17 & Tidak Valid & Reliabel & 36 & Valid & Reliabel \\
18 & Valid & Reliabel & 37 & Tidak Valid & Reliabel \\
19 & Valid & Reliabel & 38 & Valid & Reliabel \\
\hline
\end{tabular}

Sumber: Pengelola data Lampiran D.2 dan D.6

\section{Analisis Data}

\section{a. Uji N-Gain}

1) N-Gain Kemampuan Berpikir Kritis

Tabel 7

Perbandingan rata-rata N-gain (Kemampuan Berpikir Kritis)

\begin{tabular}{ccc}
\hline Kelas & N-gain & Kategori \\
\hline Eksperimen & 0,703 & Tinggi \\
Kontrol & 0,500 & Sedang
\end{tabular}

\section{Sumber: Pengelola data Lampiran D.7}

Pada tabel di atas terlihat bahwa rata-rata N-gain kelas Eksperimen yaitu 0,703 artinya terjadi peningkatan sebesar $70 \%$ dan masuk dalam katagori tinggi sedangkan kelas kontrol memiliki rata-rata $\mathrm{N}$-gain sebesar-besar 0,500 artinya terjadi peningkatan sebesar $50 \%$ dan masuk dalam kategori sedang. Itu berarti bahwa kelas eksperimen yang menggunakan media maket mengalami peningkatan kemampuan berpikir kritis yang lebih tinggi dibandingkan dengan kelas kontrol yang menggunakan media gambar.

2) N-Gain Aktivitas Belajar

Tabel 8

Perbandingan rata-rata N-gain (Aktivitas Belajar)

\begin{tabular}{ccc}
\hline Kelas & N-gain & Kategori \\
\hline Eksperimen & 0,626 & Sedang \\
Kontrol & 0,322 & Sedang
\end{tabular}

Sumber: Pengelola data Lampiran D.7 
Pada tabel di atas terlihat bahwa rata-rata $\mathrm{N}$-gain kelas eksperimen yaitu 0,626 artinya terjadi peningkatan sebesar $62 \%$ dan masuk dalam kategori sedang sedangkan kelas kontrol memiliki rata-rata $\mathrm{N}$-gain sebesar 0,322artinya terjadi peningkatan sebesar $32 \%$ dan masuk dalam kategori sedang. Itu berarti bahwa kelas eksperimen yang menggunakan media maketmengalami peningkatan aktivitas belajar yang lebih tinggi dibandingkan dengan kelas kontrol yang menggunakan media gambar. N-gain kategori tinggi, sedang dan rendah sesuai dengan tabel 7 nilai indeks $\mathrm{N}$-gain.

\section{b. Uji Normalitas}

1) Uji Normalitas Keterampilan Berpikir Kritis

Tabel 9

Hasil Uji Normalitas Data Pretes-Postes Peserta didik Pada Kelas Eksperimen Dan Kontrol

\begin{tabular}{|c|c|c|c|c|c|c|}
\hline \multirow{3}{*}{ Karakteristik } & \multicolumn{4}{|c|}{ Nilai } & \multirow{3}{*}{ Hasil } & \multirow{3}{*}{ Interpretasi } \\
\hline & \multicolumn{2}{|c|}{ Eksperimen } & \multicolumn{2}{|c|}{ Kontrol } & & \\
\hline & Pretes & Postes & Pretes & Postes & & \\
\hline Lhitung & 0,128 & 0,146 & 0,093 & 0,137 & \multirow{2}{*}{$\begin{array}{l}\text { Lhitung } \\
\leq \text { Ltabel }\end{array}$} & \multirow{2}{*}{$\begin{array}{l}\text { Berdistribusi } \\
\text { Normal }\end{array}$} \\
\hline Ltabel & 0,154 & 0,154 & 0,157 & 0,157 & & \\
\hline
\end{tabular}

\section{Sumber: Pengelola data Lampiran D.9 dan D.10}

Dari tabel normalitas di atas untuk kelas eksperimen diperoleh hasil uji normalitas untuk Lhitung pretes $=0,128$, Lhitung postes $=0,154$ sedangkan Ltabel $=0,154$. Sedangkan untuk kelas kontrol diperoleh hasil uji normalitas untuk Lhitung pretes $=$ 0,093, Lhitung postes $=0,137$, sedangkan Ltabel $=0,157$, dengan demikian pengujian normalitas pretes dan postes kelas eksperimen maupun kelas kontrol, didapatkan hasil bahwa semua data berdistribusi normal karena Lhitung $<$ Ltabel. Sehingga menjadikan $\mathrm{H}_{0}$ diterima. 
2) Uji Normalitas Aktivitas Belajar

Tabel 10

Hasil Uji Normalitas Data Pretes-Postes Peserta didik

Pada Kelas Eksperimen Dan Kontrol

\begin{tabular}{|c|c|c|c|c|c|c|}
\hline \multirow{3}{*}{ Karakteristik } & \multicolumn{4}{|c|}{ Nilai } & \multirow{3}{*}{ Hasil } & \multirow{3}{*}{ Interpretasi } \\
\hline & \multicolumn{2}{|c|}{ Eksperimen } & \multicolumn{2}{|c|}{ Kontrol } & & \\
\hline & Pretes & Postes & Pretes & Postes & & \\
\hline Lhitung & 0,103 & 0,152 & 0,156 & 0,097 & \multirow{2}{*}{$\begin{array}{l}\text { Lhitung } \\
\leq \text { Ltabel }\end{array}$} & \multirow{2}{*}{$\begin{array}{l}\text { Berdistribusi } \\
\text { Normal }\end{array}$} \\
\hline Ltabel & 0,154 & 0,154 & 0,157 & 0,157 & & \\
\hline
\end{tabular}

\section{Sumber: Pengelola data Lampiran D.11 dan D.12}

Dari tabel normalitas diatas untuk kelas eksperimen diperoleh hasil uji normalitas untuk Lhitung pretes $=0,103$, Lhitung postes $=0,152$ sedangkan Ltabel $=0,154$. Sedangkan untuk kelas kontrol diperoleh hasil uji normalitas untuk Lhitung pretes $=$ 0,156 , Lhitung postes $=0,097$, sedangkan Ltabel $=0,157$, dengan demikian pengujian normalitas pretes dan postes kelas eksperimen maupun kelas kontrol, didapatkan hasil bahwa semua data berdistribusi normal karena Lhitung $<$ Ltabel. Sehingga menjadikanHo diterima.

\section{c.Uji Homogenitas}

1) Uji Homogenitas Kemampuan Berpikir Kritis

Tabel 11

Hasil Uji Homogenitas Data Pretes-Postes Peserta didik Pada Kelas Eksperimen Dan Kontrol

\begin{tabular}{lllll}
\hline \multirow{2}{*}{ Karakteristik } & \multicolumn{3}{c}{ Nilai } & \\
\cline { 2 - 2 } & \multicolumn{2}{c}{ Eksperimen dan Kontrol } & Hasil & Interpretasi \\
\cline { 2 - 3 } & Pretes & Postes & \\
\hline Fhitung & 1,318 & 0,597 & Fhitung $\leq$ Ftabel & Homogen \\
Ftabel & 1,816 & 1,816 & & \\
\hline
\end{tabular}

\section{Sumber: Pengelola data Lampiran D.13}

Dari tabel uji homogenitas di atas, untuk kelas eksperimen dan kontrol diperoleh hasi uji homogenitas Fhitung pretes $=1,318$ dan Fhitung $=0,597$ sedangkangFtabel $=1,816$. Dengan demikian pengujian homogenitas pretes dan postes pada kelas eksperimen 
maupun kelas kontrol mendapatkan hasil Fhitung $<$ Ftabel. Sehingga mengakibatkan $\mathrm{H}_{0}$ diterima, artinya kedua sampel berasal dari populasi yang sama (homogen).

2) Uji homogenitas Aktivitas Belajar

Tabel 12

Hasil Uji Homogenitas Data Pretes-Postes Peserta didik Pada Kelas Eksperimen Dan Kontrol

Nilai

\begin{tabular}{lllll}
\cline { 2 - 3 } Karakteristik & \multicolumn{2}{c}{ Eksperimen dan Kontrol } & Hasil & Interpretasi \\
\cline { 2 - 3 } & Pretes & Postes & \\
\hline Fhitung & 1,008 & 1,763 & Fhitung $\leq$ Ftabel & Homogen \\
Ftabel & 1,799 & 1,816 & & \\
& & & &
\end{tabular}

Sumber: Pengelola data Lampiran D.14

Dari tabel uji homogenitas diatas, untuk kelas eksperimen dan kontrol diperoleh hasi uji homogenitas Fhitung pretes $=1,008$ dan Fhitung $=1,763$ sedangkanFtabel $=$ 1,816.Dengan demikian pengujian homogenitas pretes dan postes pada kelas eksperimen maupun kelas kontrol mendapatkan hasil Fhitung $<$ Ftabel. Sehingga $\mathrm{H}_{0}$ diterima, artinya kedua sampel berasal dari populasi yang sama (homogen).

\section{d. Uji Hipotesis}

1) Uji T kemampuan berpikir kritis

Tabel 13

Hasil Uji Hipotesis N-gainPeserta Didik Pada Kelas Eksperimen Dan Kelas Kontrol

\begin{tabular}{lccc}
\hline \multirow{2}{*}{ Karakteristik } & \multicolumn{2}{c}{ Nilai } & Hasil \\
\cline { 2 - 3 } & $\begin{array}{c}\text { Kelas } \\
\text { Eksperimen }\end{array}$ & $\begin{array}{c}\text { Kelas } \\
\text { Kontrol }\end{array}$ & \\
\hline Thitung & 6,344 & $\mathrm{t}_{\text {hitung }}>\mathrm{t}_{\text {tabel }}$ \\
$T_{\text {tabel }}$ & 1,998 & \\
\hline
\end{tabular}

\section{Sumber: Pengelola data Lampiran D.15}

Dari tabel uji $\mathrm{T}$ diatas, untuk kelas eksperimen dan kontrol diperoleh hasil uji $\mathrm{T}$ dengan $t_{\text {hitung }}=6,344$ dan $t_{\text {tabel }}=1,998$. Dengan demikian uji $\mathrm{T}$ pada kelas eksperimen 
maupun kelas kontrol, didapatkan hasil bahwa $\mathrm{t}_{\text {hitung }}>\mathrm{t}_{\text {tabel }} \mathrm{Maka} \boldsymbol{H}_{\boldsymbol{0}}$ ditolak artinya ada perbedaan yang signifikan nilai rata-rata tes kemampuan berpikir kritis dengan Metode Diskusi dan Ceramah.

2) Uji T Aktivitas Belajar Peserta didik

Tabel 14

Hasil Uji Hipotesis N-gainPeserta didik Pada Kelas Eksperimen dan Kelas Kontrol

\begin{tabular}{cccc}
\hline \multirow{2}{*}{ Karakteristik } & \multicolumn{2}{c}{ Nilai } & Hasil \\
\cline { 2 - 3 } & $\begin{array}{c}\text { Kelas } \\
\text { Eksperimen }\end{array}$ & $\begin{array}{c}\text { Kelas } \\
\text { Kontrol }\end{array}$ & \\
\hline Thitung & 7,600 & $\mathrm{t}_{\text {hitung }}>\mathrm{t}_{\text {tabel }}$ \\
Ttabel $_{\text {tann }}$ & 1,998 &
\end{tabular}

Dari tabel uji T diatas, untuk kelas eksperimen dan kontrol diperoleh hasi uji $\mathrm{T}$ dengan $t_{\text {hitung }}=7,600$ dan $t_{\text {tabel }}=1,998$. Dengan demikian uji $\mathrm{T}$ pada kelas eksperimen maupun kelas kontrol, didapatkan hasil bahwat ${ }_{\text {hitung }}>\mathrm{t}_{\text {tabel. }}$ Maka $\boldsymbol{H}_{\boldsymbol{0}}$ ditolak artinya ada perbedaan yang signifikan nilai rata-rata tes kemampuan berpikir kritis dengan Metode Diskusi dan Ceramah.

\section{Pembahasan}

Berdasarkan hasil analisis data penelitian menggunakan angket maupun menggunakan tes, diketahui bahwa sampel berasal dari distribusi yang normal, dan memiliki varian yang homogen artinya kedua sampel memiliki kemampuan yang sama sehingga dapat digunakan sebagai sampel dalam penelitian ini. Hasil penelitian pada angket aktivitas belajar menunjukkan rata-rata aktivitas peserta didik baik pada kelas eksperimen maupun pada kelas kontrol meningkat. Pada kelas eksperimen dimana ratarata normalitas pretes untuk angket 71,192 dan pada kelas kontrol yaitu 57,054. Sedangakan rata-rata normalitas postes untuk angket kelas eksperimen 88,977 dan pada kelas kontrol yaitu 71.241. 
Hasil penelitian menggunakan tes dimana pada kelas eksperimen menunjukan hasil rata-rata peserta didik meningkat. Pada kelas eksperimen dimana nilai rata-rata normalitas pretes untuk kemampuan berpikir kritis yaitu 47.879 dan pada kelas kontrol yaitu 38.281. Sedangkan rata-rata normalitas postes untuk kemampuan berpikir kritis kelas eksperimen yaitu 83.636 dan pada kelas kontrol yaitu 69.53. dari hasil rata-rata tersebut, diketahui bahwa penggunaan model problem posing dengan media maket dalam proses pembelajaran dapat mempengaruhi kemampuan berpikir kritis dan aktivitas belajar peserta didik kelas $\mathrm{X}$ pada materi keanekaragaman hayati di SMA Negeri 6 Bandar Lampung, karena peserta didik semangat dalam mengerjakan lembar kerja kelompok dengan melihat media maket yang telah disiapkan oleh pendidik mengakibatkan peserta didik lebih antusias dan aktif dalam kegiatan belajar mengajar.

Selanjutnya jika dilihat dari hasil analisis statistik dengan menggunakan uji $\mathrm{T}$, dari hasil uji $\mathrm{T}$ kemampuan berpikir kritis siswa $\mathrm{t}_{\text {hitung }}=6,334$ dan ttabel $=1,998$ berarti dalam hal ini $\mathrm{H}_{0}$ ditolak dan $\mathrm{H} 1$ diterima. Berdasarkan analisis uji $\mathrm{T}$ menunjukkan adanya pengaruh model problem posing dengan media maket terhadap kemampuan berpikir kritis peserta didik kelas X pada materi keanekaragaman hayati di SMA Negeri 6 Bandar Lampung. Sedangkan dari hasil uji T Aktivitas Belajar Peserta didik diperoleh $\mathrm{t}_{\text {hitung }}=7,600$ dan $\mathrm{t}_{\text {hitung }}=1,998$ berarti dalam hal ini berarti dalam hal ini $\mathrm{H}_{0}$ ditolak dan H1 diterima. Berdasarkan analisis uji T menunjukkan adanya pengaruh model problem posing dengan media maket terhadap Aktivitas Belajar Peserta didik kelas X pada materi keanekaragaman hayati di SMA Negeri 6 Bandar Lampung.

\section{KESIMPULAN}

Berdasarkan analisis data dan pengujian hipotesis yang telah dilakukan, maka dapat disimpulkan bahwa, Terdapat pengaruh model problem posing dengan media 
maket terhadap peningkatan berpikir kritis peserta didik biologi kelas x pada materi keanekaragaman hayati di SMA Negeri 6 Bandar Lampung. Hal tersebut dibuktikan dengan hasil uji hipotesis $\mathrm{T}$ (Uji T independent) diperoleh tabel $<$ thitung, yaitu 1,998< 6,334 dan Terdapat pengaruh model problem posing dengan media maket terhadap peningkatan aktivitas belajar biologi peserta didik kelas x pada materi keanekaragaman hayati di SMA Negeri 6 Bandar Lampung. Hal tersebut dibuktikan dengan hasil uji hipotesi T (Uji T independent) diperoleh ttabel $<$ thitung, yaitu 1,998 $<7,600$.

\section{DAFTAR PUSTAKA}

Alec Fisher. Berpikir Kritis Sebuah Pengantar. Jakarta: Erlangga, 2008.

Amri S Dan Ahmadi. Proses Pembelajaran Kreatif Dan Inovatif Dalam Kelas. Jakarta: PT Prestasi Pustakaraya, 2010.

Anas Sudijono. Pengantar Evaluasi Pendidikan (cet. XXII). Jakarta: Raja Grafindo Persada, 2010.

Arief Sadiman dkk. Media Pendidikan Pengertian, Pengembangan Dan Pemanfaatan. Jakarta: Rajawali Pers, 2008.

ArifPribadi dan Yanti Herlanti, BIOLOGI untuk SMA/MA Kelas X Kurikulum 2013. Jakarta: Yudhistira, 2014.

Azhar Arsyad. Media Pembelajaran. Jakarta: PT Raja Grafindo Persada, 2013.

Bestari Dwi Handayani," Efektivitas Penerapan Metode Problem Posing Dan Tugas Terstruktur Terhadap Prestasi Belajar Siswa”. Jurnal Forum Kependidikan, Vol. 28 No. 1 (Januari 2016), h. 2.

Budiyono. Statistika Untuk Penelitian. Surakarta: UNS Press, 2013.

Colleta V.P. dan Phillips J.A. Interpreting FCI Scores: Normalized Gain, Preinstruction Scoreand Scientific Reasoning Ability. California: Departement of Physics Layola Marymount University, 2005.

Daryanto.PanduanProses Pembelajaran Teori Dan Praktik Dalam Pengembangan professionalisme Guru. Jakarta: AV Publisher, 2009.

Departemen Agama RI. Al-Qur'an dan Terjemahannya. Bandung: CV. Diponegoro, 2008. 
Fatimatuzzahra.Pengaruh Penggunaan Media Maket Dengan Model Inkuiri Terpimpin Terhadap Kemampuan Berpikir Kritis Siswa Pada Materi Pokok Ekosistem. Lampung: Universitas Lampung, 2011.

Hamdani. Strategi Belajar Mengajar. Bandung: CV Pustaka Setia, 2011.

Hartono. PAIKEM Pembelajaran Aktif, Inovatif, Kreatif, Efektif, dan Menyenangkan. Pekanbaru: Zanafa, 2008.

Herniza L. Pengaruh Media Audio-Visual Melalui Model THT Terhadap Kemampuan Berpikir Kritis Siswa Pada Materi Pokok Sistem Pernafasan. Lampung: Universitas Lampung, 2011.

Irnaningtyas. BIOLOGI untuk SMA/MA Kelas X Kurikullum 2013. Jakarta: Erlangga,2014.

Kunandar. Guru Profesional Implementasi Kurikulum Tingkat Satuan Pendidikan (KTSP) dan Sukses dalam Sertifikasi Guru. Jakarta: Rajawali Pers, 2004.

Kinanti Ayu Puji Lestari,"Penerapan Model Pembelajaran Problem Posing Untuk Mengajarkan Materi Botani Yang Teritegrasi Pada Siswa Kelas XI". Jurnal UNESA, Vol. 2 No. 3 (Januari 2016), h. 279.

Hartono D Mamu,'Pengaruh Strategi Pembelajaran, Kemampuan Akademik Dan Interaksinya Terhadap Keterampilan Berpikir Kritis Dan Hasil Belajar Kognitif IPA Biologi”.Jurnal Pendidikan Sains, Vol. 2 No. 1 (Maret 2016), h. 2.

Margono. Metode Penelitian Pendidikan. Jakarta: PT Rineka Cipta, 2000.

Muhammad Ali. Guru Dalam Proses Belajar Mengajar. Bandung: Sinar Baru Algensindo, 2008.

Novalia dan Muhamad Syazali. Olah Data Penelitian Pendidikan. Bandar Lampung:Anugrah Utama Raharja (AURA), 2014.

Oemar Hamalik. Proses Belajar Mengajar. Bandung: Rosida, 2004.

Ratna WilisDahar. Teori-Teori Belajar Dan Pembelajaran. Jakarta: Erlangga, 2002.

Ratna Kartika Irawati," Pengaruh Model Problem Solving Dan Problem Posing Serta Kemampuan Awal Terhadap Hasil Belajar Sisw”. Jurnal Pendidikan Sains, Vol. 2 No. 4 (Januari 2016), h. 185.

Sudaryono. Pengembangan Intrumen Penelitian Pendidikan. Yogyakarta: Graha Ilmu, 20013

Sudjana. Metode Statistik. Bandung: Tarsito, 2001.

Sugiyono. Metode penelitian kualitatif kuantitatif dan R\&D. Bandung: Alfabeta, 2012. 
Suharsimin Arikunto. Dasar-Dasar Evaluasi Pendidikan. Jakarta: Bumi Aksara, 2013

Suharsimi Arikunto. Prosedur Penelitian Suatu Pendekatan Praktik (cet.IV). Jakarta: Rineka Cipta, 2010.

Sumarna Surapranata, Analisis, Validasi, Reliabilitas, Dan Intrepretasi Hasil Tes, Implementasi Kurikulum 2004. Bandung: PT Remaja Rosdakarya, 2005.

Trianto. Mendesain Model Pembelajaran Inovatif-Progresif. Jakarta: Kencana Media Group, 2009.

Model Pembelajaran Terpadu. Jakarta: Kencana Prenada Media Group, 2007.

Hisyam Zaini. Strategi Pembelajaran Aktif . Yogyakarta: Insan Madani CTDS, 2008 